\title{
A Fiqh Reconstruction in Company Zakat Accounting
}

DOI 10.18196/AlIJIS.2020.0120.175-208

\section{IRFAN, ${ }^{1}$ MUHYARSYAH ${ }^{2}$}

Fakultas Ekonomi dan Bisnis, Universitas Muhammadiyah Sumatera Utara 1,2

E-mail: irfanumsu@gmail.com

\begin{abstract}
The paper aims to explore the concept of the company from the aspects of Islamic law (figh) and sharia, as the basis in determining the company as muzakki, thus raising the legal obligation for companies to pay zakat through the zakat accounting calculation method. This study is designed to reconstruct the concepts of figh and sharia in muamalah (economic) activities within the framework of aqidah, sharia and akhlak through ijtihad. The research uses qualitative analysis, through a literature study approach by exploring various classical and contemporary sources. This paper found that the company is synonymous as syirkah on the basis of syakhshiyyah i'tibariyyah (spiritual entity) or syakhshiyyah hukmiyyah, referred to as al-dhimmah, that is, inherent traits of humans, as expert al-form (the right to receive) and syahhshiyyah al-ada (the right to fulfill responsibilities). So, the company as the subject of zakat has an obligation to pay zakat based on five principles inherent in the company as muzakki. The calculations are carried out by using the company zakat accounting method based on established standards (AAOIFI), (MASB), and (IAI). The determination of companies as subjects of zakat, which has the obligation to pay zakat, certainly has positive implications for the realization of a fair and equitable distribution of wealth, as well as the emergence of corporate social responsibility (collectively) and the responsibility of a Muslim (individually) in realizing his worship. to Allah SWT, an increase in community welfare can be achieved.

Keywords: zakat, company, figh, mu'amalah, accounting.
\end{abstract}

\section{ABSTRAK}

Tujuan tulisan ini adalah untuk mengeksplorasi konsep perusahaan dari aspek hukum Islam (fiqh) dan syariah, sebagai dasar dalam menetapkan perusahaan sebagai muzakki, sehingga memunculkan kewajiban hukum bagi perusahaan untuk membayar zakat melalui metode perhitungan akuntasi zakat. Kajian ini disain untuk melakukan rekonstruksi terhadap konsep fiqh dan syariah dalam aktivitas muamalah (ekonomi) dalam kerangka aqidah, syariah dan akhlak melalui ijtihad. Penelitian 
menggunakan analisa kualitatif, melalui pendekatan studi kepustakaan dengan mengeksplorasi berbagai sumber- referensi klasik dan kotemporer. Tulisan ini menemukan bahwa perusahaan disinonimkan sebagai syirkah dengan dasar syakhshiyyah i'tibariyyah (entitas spritual) atau syakhshiyyah hukmiyyah, disebut sebagai al-dhimmah yaitu terdapat sifat yang melekat pada manusia, sebagai ahliyah al wujud (hak menerima) dan ahliyyah al-ada (hak menunaikan tanggung jawab). Maka perusahaan sebagai subjek zakat memiliki kewajiban dalam membayar zakat berdasarkan lima prinsip yang melekat pada perusahaan sebagai muzakki. Adapun perhitungannya dilakukan menggunakan metode akutansi zakat perusahaan berdasarkan standar baku yang ditetapkan (AAOIFI), (MASB), dan (IAI). Penetapan perusahaan sebagai subjek zakat, yang memiliki kewajiban dalam membayar zakat, tentu memiliki implikasi positif bagi terealisasinya distribusi kekayaan secara adil dan merata, serta munculnya tanggungjawab sosial perusahaan (secara kolektif) dan tanggungjawab seorang Muslim (secara individu) dalam merealisasikan ibadahnya kepada Allah SWT, peningkatan kesejehteraan masyarakata akan dapat tercapai.

Kata Kunci:zakat, perusahaan, figh, mu'amalah, akuntansi.

\section{INTRODUCTION}

Islam is a religion revealed by Allah SWT to the Prophet Muhammad, to provide guidance and happiness to humanity, ${ }^{1}$ by conveying His teachings, ${ }^{2}$ in order to obey the will and will of God, and obey His laws. ${ }^{2}$ In Islamic language comes from the word "Salm" (السَّلْم) means peace (QS Al Anfaal (8): 61; Al Hujuraat (49): 9), "aslama" (أَسََّ) means surrender (Surah Al Baqarah (QS) 2): 112; QS An Nisaa '(4): 125; QS Al An'am (6): 162; QS Al Imran (3):

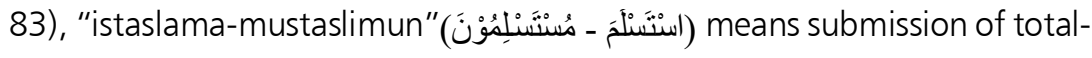
ity to Allah SWT (Surah Ash Shaaffat (37): 26; Surah Al Baqarah (2): 208), "saliim" (سلّم) means holy (Surah Asy Syu'araa '(26): 89; Surah Maryam (19):

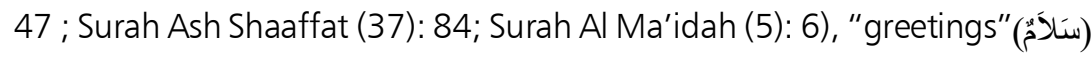
means survivors and prosperity (Surah Maryam (19): 47).

The basic essence of Islamic teaching (shari'ah islamiyah) is aqidah, sharia, and akhlak ${ }^{2}$ and jihad ${ }^{3}$ whose implementation is based on the Al-Quran and As-Sunnah (Hadith). Aqidah as a form of belief and faith of a Muslim that can be used as a basic foundation in carrying out mu'amalah (economic) activities in accordance with human nature as caliph fil ardh, which has an honourable position as the caliph of God (QS Al Baqarah (2): 30) as a substitute for humans before (Surah Yunus (10): 14) to be the ruler of the earth (Surah Al An'am (6): 165) in order to carry out the mandate of God (Surah Al 
Ahzab (33): 72) in setting decisions fairly (QS Shad (38): 26) so that they can dominate and prosper the earth (QS Huud (11): 61).

Sharia is the norm (rules) governing human relations with God (hablum minallah), humans with humans (hablum minannas), humans with nature (hablum minalam), ${ }^{4}$ which is based on God's law ${ }^{4}$ so as to realize the benefits and eliminate the harms for humans. ${ }^{5}$ In the context of mu'amalah (economics), sharia is the source and basis in realizing figh as knowledge of Allah's rules on the behavior and actions of the mukallaf, about the obligatory, sunnah, makruh, mubah which are sourced from the Qur'an and AlHadith, ${ }^{5}$ as well as the emergence of allegations (zhann), ${ }^{5}$ concerning shariah laws' through ljtihad. ${ }^{6}$ So, in figh mu'amalah (economy) required the principles of worship (al-tawhid), equality (al-musawat), freedom (al-hurriyat), justice (al-'adl), help-help (al-ta'awun) and tolerance (al-tasamuh). ${ }^{6}$

Akhlak is a condition that persist in the human psyche, ${ }^{6}$ consisting of lust, ${ }^{7}$ which have good moral character (al khuluq al hasan) and bad (al khuluq as sayyi $\left.{ }^{\prime}\right)^{8}$ without the thought process, ${ }^{9}$ and pondering ${ }^{10}$ in obtaining happiness ${ }^{11}$ based on place and position, through cosmic evolution. ${ }^{12}$ The moral position in Islam in principle can be an entry point in achieving the benefit of all humanity in muamalah activity. Islam instils in the souls of every Muslim to apply the nature of honesty, justice, goodness, truth, expediency, happiness, togetherness, balance, responsibility, and wisdom, within the framework of the nature of as-shiddiq, al-amanah, tablig, al-fathanah, ${ }^{13}$ alistiqamah, ${ }^{14}$ and qana'ah. ${ }^{15}$

In Arabic Lisanul, Ibn Munzir suggested that muamalah came from the words aamala, yuamilu, muamalat which meant "you work with him/deal with trade", "associate with him", "befriend him", "consult with him". ${ }^{16}$ But it is literally interpreted as behavior towards others based on relationships of interest. But the interests that are built must be based on the values of aqeedah, sharia, and morals which are sourced from the Koran and Al-Hadith (dalil naqly) and ljtihad (dalil Aqly) in the form of ijma', qiyas, istihsan, istislah, maslahah murshalah, sududz dzariah), Istishab, ${ }^{16}$ ' $u r f .{ }^{17}$

Basically, mu'amalah activities according to Al Ghazali, ${ }^{18}$ in The Encyclopaedia of Islam is a term that refers to Islamic law in bilateral contract activities and ritual worship. Furthermore, Al-Ghazali ${ }^{19}$ also stated mu'amalah as a transaction activity in granting and receiving credit to someone with collateral. ${ }^{19}$ Mu'amalah contains Islamic law where Allah's rights form the basis of human obligations in carrying out worship (al ibadat) such as sahadat, prayer, 
zakat, fasting, pilgrimage. The rights of beings (humans) are formed from basic habits (al adat) which can be seen from two points of view, namely, first, exchange (al-mu'amalat) such as buyers, sellers, associations, givers, borrowers, debts, etc.. Second, contracts (agreements) (al-mu'akada) such as marriage, divorce, freedom from slavery, the right to work, and others.

The implementation of mu'amalah activities in economic activities will certainly experience significant developments, both in terms of form, type, model and method of application. This condition certainly needs to be reconstructed against various figh concepts in Islamic thought, to be able to be elaborated in a time frame and place as long as it does not conflict with the values of aqeedah, sharia and morals, as well as at the level of shak or zhann (still uncertain).

Islamic scholars have discussed the problem of reconstructing Islamic thought in mu'amalah activities, including lqbal, ${ }^{20}$ carrying out the reconstruction of fiqh (jurisprudence) which has been considered an absolute doctrine due to the closure of the doors of ijtihad, while Ibn Taymiyyah and Sayuti argued that the need for freedom of jihad, so that the rule of law and the rules of religion do not become a unity, as a Hegelian and Bergasonian concept of the lord's God, time, and place. ${ }^{21}$ Then it is necessary to continue the reconstruction of figh (jurisprudence) by penetrating thinking with a new experience spirit, but by not adjusting to the conditions of modern life. ${ }^{22}$ Faruqi, ${ }^{23}$ points out that renowned Islamic jurists, Shafi'i, Abu Hanifah, Imam Malik and Ahmad Ibn Hambal who understand and understand about ushul figh deeply state that figh is not a general principle of Islamic law, but is the first principle in understanding Islam for life and reality. Therefore, changes in the modernization of the social life of society can be done by reconstructing fiqh by legal experts who have the capability, to encourage reconciliation (reform), social reformation of Islamic norms and laws. ${ }^{24}$

Reconstruction of figh in mu'amalah activities needs to be done in achieving the problem of mursalah in accordance with the objectives of sharia (maqasid syariah)..$^{25}$ The emergence of modernization in worldly life in social and economic activities, of course, the Islamic Ummah requires the concept of figh mu'amalah in order to reduce errors and irregularities in carrying out mu'amalah activities. Discussion about fiqh mu'amalah has been widely written by Islamic scholars including Zuhaily (2007), ${ }^{26}$ Suhendi (2002), ${ }^{27}$ Haroen (2000), ${ }^{28}$ Afandi (2009), ${ }^{29}$ Ayob (2008), ${ }^{30}$ Ghazaly, et al (2010), ${ }^{31}$ Mustofa (2016), ${ }^{32}$ Moh. Dali (2008), ${ }^{33}$ Ghazi and Ghazi (2016), ${ }^{34}$ Abdullah (2013), ${ }^{35}$ 
Hadzami (2012). ${ }^{36}$ Various thoughts in the figh of mu'amalah especially in the issue of zakat compiled by Muslim scholars have given new insights and enlightenment in mu'amalah activities, especially in the economic aspects especially in the understanding of corporate zakat. However, the discussion of figh mu'amalah in the context of zakat has not been arranged specifically, but efforts to understand companies as zakat objects have been written by Qardhawi (2014), ${ }^{37}$ Zayas (2008), ${ }^{38}$ Obaidullah (2015). ${ }^{39}$ The limited discussion regarding company zakat especially its implementation uses zakat accounting, so an in-depth study is needed, through a reconstruction of the concept of fiqh at the level of ijtihad, so that new ideas arise in mu'amalah figh, so as to provide a comprehensive solution, in terms of corporate obligations to issue zakat through the method of accounting calculation from the perspective of figh and sharia. So, this paper aims to explore the concept of the company from the aspects of Islamic law (fiqh) and sharia, as the basis for establishing the company as muzakki, thus raising the legal obligation for companies to pay zakat through the zakat accounting calculation method.

\section{COMPANIES IN THE CONCEPT OF FIQH}

The characteristics, types, and forms of establishing a company in the modern era and globalization at this time, if referring to the writings of classical scholars in the field of figh, can be justified as something new. Literally not even existed at the time of the Prophet, friends and tabi' tabi'in. However, fundamentally the discussion about the basic essence of the establishment of a company has been discussed implicitly and in general (not specific).

This condition certainly requires an in-depth exploration to get references or in-depth and clear references through studies in the interpretation of the Qur'an and Hadith and ijtihad from figh scholars, so that the meanings of the word "company" or related and synonymous with it can be understood. This is because, information, explanations and research, especially those conducted by the fuqaha (figh experts) in the past, have not specifically discussed the characteristics, types, and forms of a company that exist today. But there is no mention of the vocabulary of "companies" at the time, certainly does not mean the connotation of the company as mu'amalah (economic) economic activity is not justified (prohibited) in figh and sharia.

In the concept of syirkah (company), ulama generally divide into two groups, namely syirakah amlak and syirkah 'uqud. ${ }^{40}$ Syirkah amlak is very 
closely related to togetherness in ownership, there are those who call it a union in ownership/ownership rights to the substance of goods. Meanwhile, syirkah 'uqud relates to transactions/property rights development, some call it aqad musyarakah/aqad union. ${ }^{41}$ For example, a company founded by three people, the ownership of the company is owned by the three founders, although in different proportions. Thus, if an obligation arises from a company, such as in paying taxes, then the obligation is not charged separately to each of the three people, but rather is borne by the company as a whole. ${ }^{42}$

The next most important thing is related to the position of corporate legal entities in Islamic teaching. Because the correlation is related to the determination of companies as subjects of zakat who have the obligation to pay zakat. Because the subject of zakat which is subject to obligation in paying zakat is always identified with individuals. Then the thought arose regarding the determination of the company as the subject of zakat by identifying the company as an individual. So contemporary scholars bring up the term syakhshiyyah i'tibariyyah (spiritual entity) or syakhshiyyah hukmiyyah, which in positive law is called a recht person (legal body). ${ }^{43}$ In the sense of Hafidhuddin, ${ }^{44}$ companies are considered to have the same characteristics and characteristics as humans, in the term figh referred to as al-Dhimmah, ${ }^{45}$ meaning that there are traits inherent in humans, namely as experts of alwujud (right of acceptance) and expert of al-ada (right to fulfill responsibility). ${ }^{46}$ Then the results of the company's business transactions are shared with the shareholders, as well as the company's obligations they will share, including obligations to Allah in the form of Zakat. ${ }^{47}$ The view of Zaid, ${ }^{48}$ syakhshiyyah i'tibariyyah as a separation of investment activities from individuals who fund the investment activities, but the owner of the company automatically has an influence in exercising his rights and obligations in paying zakat. Zaid, ${ }^{49}$ even suggested that syakhshiyyah i'tibariyyah also affects syakhshiyyah ma'nawiyyah which has a significant principle and influences accounting activities and profits from investment. So syakhshiyyah i'tibariyyah must be distinguished as a concept and its effect on the rights and obligations of the owner of the company (syirkah).

In the history of Islam, there are several bodies or institutions that have human-like characteristics. For example, Baitul Maal which fulfils the characteristics of syakhshiyyah i'tibariyyah. Because Baitul Maal is an institution, ${ }^{50}$ which is managed by a group of people with a specific purpose, so it has rights and obligations like humans. Where the right of Baitul Maal is to be- 
come an heir for people who do not have an heir, and the obligation is to meet the needs of the poor and needy people who are unable to meet their needs. The company, in the current context, can act like a human being, that is, sue and be sued, have assets and assets separated from shareholders' wealth, make purchases and sales, and so on.

So, it can be concluded that the company, both in the concept of syirkah and syakhshiyyah i'tibariyyah, may be a source of contemporary zakat assets. In accordance with the results of the International Zakat Conference I in Kuwait on April 3, 1984, it was confirmed that the company zakat can be paid if it meets the requirements, where the company zakat is analogous to the trade zakat. Thus, the Nisab is 85 grams of gold, and is released $2.5 \%$ once a year.

\section{COMPANY AS A SUBJECT OF ZAKAT}

Zakat has become an important instrument in the process of distributing wealth among Muslims. In principle the collection and distribution of zakat is independently (independently) conducted by an Islamic jurist with/without legal entity. The country only functions as a regulator in maximizing the activities of zakat institutions. Thus, the payment of zakat is the consciousness arising from the existence of human beings as beings of Allah SWT to fulfil their obligations in accordance with shariah values, so that zakat is considered a worship of mahdhah and ghairu mahdhah because it covers the forms of zakat al-fitr and zakat al-mal. The payment of zakat is not only an obligation to a Muslim who can afford only to the community and the country, but an obligation that must be fulfilled by Allah's command. Therefore Lewis, ${ }^{51}$ zakat is not just about donations, but rather its emphasis is on rights (claims) and claims. According to Abdul Rahim, ${ }^{52}$ Muslim companies are obligated to pay zakat as their contribution to social welfare and fulfill their social responsibility and final responsibility to Allah Almighty.

Zakat is one of the basic principles of Islam that has a bearing on the accounting system. The reason for valuing an individual's wealth should be calculated by quantitative value. Lewis. ${ }^{53}$ Therefore, calculations should be done through accounting in the Islamic perspective, which according to Haniffa and Hudaib, ${ }^{54}$ as a guarantee function aimed at upholding social justice through procedures, routines, objective measurements, oversight and formal reporting in accordance with Islamic principles of Islam. The study of the company as a muzakki or a subject of zakat, is a person subject to the obligation to pay 
zakat, can be seen in terms of compulsory zakat, which is related to two parts. First, the condition of the individual muzakki itself. Second, the conditions on the property that the zakat must be issued.

Calculating zakat by using the zakat accounting method can refer to the basic rules that are used as a concept in calculating corporate zakat. In this case there are two basics on the importance of adherence to using the zakat accounting method. First, make sure to get to the zakat-rich wealth. Second, ensuring that only those who qualify are responsible for fulfilling their zakat obligations. ${ }^{55}$ Implementing a fair accounting method and reporting system will ensure equitable redistribution of wealth and income through zakat payments. ${ }^{56}$

\section{COMPANY AS A MUZAKKI IN THE FIQH PERSPECTIVE}

In Islam, property is to be expended in the way of Allah (Q.S. Al-Baqarah (2): 267) as it is through zakat payment. The issued zakat works for selfpurification (Q.S. At-Taubah (9): 103). In addition to the Quran, the Hadith also provides examples of the obligations and regulations for issuing zakat (Bukihari Sahih, No. 1308; Bukhari Sahih, No. 1361; Muslim Sahih, No. 1784; Bukhari Sahih, No. 1355).

Islam encourages zakat to be practiced by every Muslim, both personal and corporate. In Indonesian law, among the objects of zakat that are required to issue zakat are trade and enterprise activities (Law No. 38 of 1999). It can be emphasized that the company can be classified as a party obligated to pay zakat and attach its connotation as a muzakki. Zakat collection is no longer limited to individual muzakki. However, muzakki as a subject of zakat can extend its understanding to institutions such as companies. ${ }^{57}$

Companies run by Islamic principles are obligated to pay zakat in fulfilling their obligations as a shakhshiyyah i'tibariyyah. This obligation is not confined to Shariah awareness and faith, but the obligation to issue zakat can also serve as a contribution to social well-being and fulfil social responsibility and absolute responsibility to God. ${ }^{58}$ The company is obligated to pay zakat on all valuables and it is a matter of zakatability or wealth. The basic principle of zakat on corporate wealth is based on merchandise ('Urud al-tijarah) which is what is acquired for the purpose of trading for profit. ${ }^{59}$

The obligatory requirements of zakat are related to the muzakki, according to Al-Husaini, 60 there are two, namely, Islam and independence (not slave). Further Al-Zuhaily's, ${ }^{61}$ adds two other conditions, namely: baligh and logic. 
While the obligatory zakat requirements related to property are described by Qaradawi, 62 there are six, namely: full, growing, reasonably priced, more than ordinary, debt-free, and valid in one-year (haul).

However, the conditions on the muzakki itself do not automatically give the muzakki the obligation to issue zakat. The obligation arises only when the conditions on the property are fulfilled. That is, in order to establish a zakat obligation, one must take into account the two conditions, the condition of the muzakki and the condition of the property it has. According to Qaradawi, ${ }^{63}$ there are six principles of zakat rules and conditions that can be used to formulate the characteristics of a muzakki as the person or persons required to pay zakat. The six principles are: (1) the principle of confidence, (2) the principle of justice, (3) the principle of productivity or up to the time (haul), (4) the principle of reasoning, (5) the principle of convenience, and (6) the principle freedom (independence). Meanwhile, al-Zuhaily made six requirements of the muzakki subject to zakat, namely: (1) Islam, (2) Baligh-minded, (3) Free or independent, (4) Owning property until nisab and haul, (5) Full ownership (al-milkiyah at-tammah), and (6) muzakki already meet basic requirements, before paying zakat.

The question is, first of all, when muzakki are required to be Muslim, barbaric and independent, then what about unbelievers living in a Muslim country, children and crazy people, as well as slaves, when they have the property in terms of compulsory requirements has fulfilled the obligation to pay the zakat. Second, while in the past, ownership of property was more individual, while in modern times many ownerships of property were collectively in the form of corporations, foundations, cooperatives and others, then were all subject to zakat?

Regarding the terms of the Muslim muzakki, the jurisprudence sets out zakat obligations for Muslims only. The reason is that zakat is one of the pillars of Islam, so it is not obligatory for the disbelievers, as well as for prayers and fasting. This statement raised a number of questions, in reports from Umar Bin Khatab and several second-generation people (tabi'in) saying that zakat can be performed for infidels of zimmi. If they can receive zakat, then why Muslims may not receive zakat from the rich among them? Qaradawi, ${ }^{64}$ emphasized that there is no reason not to collect zakat from the infidels, in view of the obligation and the use of zakat is monetized as tax from non-Muslims (Kafir zimmi).

With regard to the conditions of puberty and the intellect, according to 
Imam Abu Hanifah, it is not obligatory to pay alms to children and crazy people, since zakat includes worship offered to adults such as prayer, fasting and pilgrimage. However, the Imam Hanafi obligates tithe zakat for young men and women, if they meet the requirements of zakat (adequate) zakat, and must be paid by their guardian. In worship there must be intentions, while the intentions of children or madmen cannot be accounted for as they do not belong to the mukallaf. ${ }^{65}$ Jumhur scholars believe that children are not only obligated to zakat al-fitr, but also must be zakat al-mal. When the child has a treasure that is a must. The proposition is the prophetic narration of the Prophet Imam Malik of Umar bin Khatab:

"The Messenger of Allah (may peace be upon him) said:" Exercise orphan wealth, so that (alms) may not be eaten alms" (Imam Malik, No. 523).

This hadith has made it clear that the orphan's property is still obligated to zakat, as did Aisha, who always issued zakat from the orphanage that she raised. As for the free provision of zakat, where a slave is not obligated to zakat, because a slave/slave has no legal ability, that is, he has no ownership rights and is not entitled to any transaction. Scholars are well-versed in this, which is that slaves are given great gifts by their employers. The Hanafi and the Shafi'i scholars saw it as compulsory for the zakat to be issued, but the scholars Maliki and Ahmad, did not require it at all. ${ }^{66}$ The second issue, on whether or not a company is obligated to issue a zakat, was answered in the first International Proceedings of the zakat in Kuwait on 29th 1404 H / 3 April $1984, M$, that the company was obligated to issue a zakat, due to the existence of the company as a legal entity). The company, according to the results of the muktamar (conference), is either a syakhsan i'tibaran (a legal entity considered by the people) or a hukmiyyah syakhshiyyah. Therefore, companies include muzakki or zakat subjects. ${ }^{67}$

\section{CORPORATE ZAKAT ACCOUNTING PRINCIPLES}

Based on the exploratory results of the thinking presented in the literature study and considering the principles put forward by the researchers, the principle of accounting for corporate zakat can be summarized in five main principles. These principles include: 1). Ownership is dominated by individuals or groups of Muslims; 2). Business must be lawful; 3). Company assets can be valued; 4). The company's assets can grow and reduce the company's wealth to 85 grams of gold. 


\section{Ownership Owned by Muslims}

Ownership in Islam is property owned in accordance with religious values, in the sense that property ownership must be in accordance with Shariah rules. ${ }^{68}$ Human property is in fact the property of Allah SWT, not the absolute possession of man. ${ }^{69}$ This is revealed by Allah Almighty in the Quran, that it is Allah who possesses and dominates the universe (QS Al-Baqarah (2): 284; QS Al-Imran (3): 189; QS Al-Furqan (25): 2). Ownership in Islam is divided into three parts: 1). individual ownership; 2). public ownership; 3). state ownership. $^{70}$

This is a condition that has been put forward/established by Islamic scholars in the matter of paying the zakat by reference (al-milkut taka). As the word of God says:

".... and give them of the gift of Allah that is yours" (Q.S. An-Nur (24): 33).

"You will never achieve good, until you spend some of your precious possessions." (Muslim, Muslim No. 1664)

The above two verses (and many other passages) can be clearly understood that Allah Almighty as the owner of the property actually relied on the mention of property as a sign of respect and as a testament to them that a human responsibility arose as the caliph of Allah. SWT on earth. God created man as caliph on earth, man is blessed with the right of ownership (milikiyyah) over property (mall) so that he can carry out duties and obligations to himself, family, community and God in a lawful way. ${ }^{71}$ As examples related to ownership of one of these are financial assets, such as currency and currency exchangeable assets, can be the subject of zakat, as currencies can replace gold and silver as intermediaries (tools) in exchange and value-saving. ${ }^{72}$

Ownership is essentially a person's full power to utilize his or her property through various means of obtaining it in accordance with the rules and conditions that Allah Almighty has given. Similarly, in the above provisions we can understand that ownership of the property that is required to be practiced is only the property of a Muslim as described in the terms of the muzakki. Therefore, companies that are wholly owned by Muslim entrepreneurs are obligated to pay zakat in their honour and glory.

In a cooperative (syirkah) company, if the person who attends is all Mus$\mathrm{lim}$, then zakat is issued before it is distributed to the parties. But when the people involved in the syirkah (syirkah) are non-Muslim, then zakat is only issued to Muslims if the number exceeds nisab. ${ }^{73}$ However, in reference to 
Qardhawi's, ${ }^{74}$ view of zimmi infidelity, corporate zakat expenditure can be made entirely without distinguishing the religious background of the people who do the cooperation (syirkah), but the interpretation of the zakat issued by one company as zakat al-ma/ while the second as a tax.

\section{The Field of Mandatory Laws}

Muslims are obliged to seek and trade in halal ways (Q.S. Al-Baqarah (2): 275; Q.S. Al-Baqarah (2): 16). Halal business transactions are all transactions allowed by Islamic sharia. Obviousness can be seen from two aspects, namely, the objectivity of the object to which it is transacted and the refinement in a transactional way. ${ }^{75}$ In addition to halal, the business must not raise any doubt (syubhat), either in its indications (qara'in), its consequences (lawahiq), its causes (sawabiq), and its substitutes, exchanges, payments. ${ }^{76}$ The concept of iwad (counter value in practice) should be the focus of business, which is based on three principles: risk (gharm), liability (dhaman), and effort or value (khiyar). ${ }^{77}$

The commodity of commodities and commodity trade are absolute in Islamic law. Its existence is something different and a boon to the Shariah economic system of the conventional economy. Halal for Muslims is a fundamental ideology and necessity, while halal for non-Muslims is a protection against preventing anything that can harm individuals and society.

The relationship between zakat obligation and product and commodity legalization is closely linked and united. This is not to be overlooked for a number of reasons: First, zakat is worship, then consumption of halal commodities and commodities is worship, therefore the expenditure of zakat on a company is one of products and commodities that produce something halal. Secondly, zakat is intended to be lively and halal is the protection of the human being in his life, then the imposition of zakat on the company due to the products and commodities produced does not cause harm and is dangerous to life, so the people feel safe in consuming it. Third, Zakat would not be possible without ownership and unauthorized ownership of Islam without a lawful course, so the zakat determination on the company should be based on ownership obtained through the process authorized by Allah SWT. Thus, it can be concluded that corporate zakat is only derived from halal products.

According to Hafidhuddin, ${ }^{78}$ the property should be obtained in a good and lawful way, meaning that the illegal, substantive property of the master or the means of obtaining it will not be subject to zakat, as Allah Almighty 
will not accept it. Illegal properties, whether in substance such as alcohol and pigs or companies that engage in illegal activities such as gambling, are not subject to the provisions of the subject of zakat.

\section{Assetable Company Assets}

Selling(البيع) is the exchange of property with property to be their own right, ${ }^{79}$ proposes as the process of exchanging something with another, by transferring ownership. ${ }^{80}$ Selling is the most important source of sustenance in human life as it was put forth by Prophet Muhammad. While in the figh you do not value the valuable things that cannot be traded so there is no trade and there is no zakat to be issued. The company's assets must be assessed to be able to be calculated on the basis of the amount of zakat required to be issued. Without valuation of assets there is no calculation of zakat rate. ${ }^{81}$ So, in principle the property paid for by the zakat, its value should reach the nisab, more than the basic necessities, free of debt, and fully owned by the owner. However, while the muzakki is an institution with various asset classifications, liabilities, and business activities, the zakat calculation method also appears to vary with the aim of generating optimal zakat payment figures. ${ }^{82}$

\section{Company Assets Can Grow}

The development of a company's assets is defined as the incremental value of a product and a commodity. Development also means current and non-current assets (fixed assets). So, in the calculation of the zakat the company will pay the zakat based on its current assets. A property develops when a property is able to generate income, profit or additional value to its previous property. Growth can also occur through business outcomes such as business items. Therefore, property that cannot grow is not obligated to zakat. This immovable property is referred to as property for personal use such as houses, vehicles, furniture and the like. ${ }^{83}$

The property charged to zakat is a property that develops or has the potential to grow (al-name). Zakat-charged property must be the property that is being cultivated to the point of generating profit. The condition of the developing property is based on the assets imposed at the time of the Prophet who was relatively fertile. For example, livestock raised for produce, agricultural produce, gold and silver, money and business goods. ${ }^{84}$ The settlement 
of zakat-based property is also through the efforts of the actions taken to generate income and profit, and the zakat-based property is productive. Assignments of the components of the productive property may be presented as follows: cash, non-cash financial instruments, inventory of final goods, fixed assets of the company, net trade receivable, in the case of property management, long-term assets.

\section{Corporate Minimum Wealth Standard Equivalent to 85 Grams of Gold}

The minimum standard of ownership of wealth is not something new in the context of zakat. The minimum standard of wealth in the classical figh literature for zakat must be met with nisab, the measure in the examination of nisab on the wealth possessed for zakat by the majority of fiqh scholars can be converted to a value of 20 dinars (gold coin at 4.25 grams / dinar). This nisab is the highest nisab in zakat. The ownership of the fortune that the nisab is obliged to make out of his zakat is the wealth that goes beyond the basic needs of a person from the prescribed nisab. Therefore, companies with assets of less than 85 grams of gold are not required to pay the zakat and do not include the wealth they deserve. In addition to the five principles of zakat accounting presented above, according to the International Proof of Accountability in Kuwait, other technical requirements are as follows:

First, there are laws or regulations that require companies to issue zakat. In the time of the Messenger of Allah the payment of zakat was governmental authority so that we could find the sanction of the government for those who do not want or refuse to pay zakat, by confiscating some of one's property. Similarly, during Abu Bakr as-Siddiq he proclaimed the power of the government and the state to restore the obedience of a group of people who refused to pay zakat after the death of the Messenger of Allah. With the government regulation, then the zakat management tools in a country are complete.

Second, the law of corporate establishment (Basic Budget and Household Budget) must state matters related to the corporate zakat expenditure. Internal rules can only be implemented when the collective consciousness and desire, collectively of the corporate managers to issue their corporate zakat, therefore internal factors will not prevent the company from issuing zakat in interacting with the system's rules. 
Third, the General Meeting of Shareholders (AGMs) held by the company can provide a recommendation of the obligations in the company's zakat expenditure. This should be supported by all members of the meeting in order to instil a high level of awareness and spirit in carrying out religious orders in order to realize the obligation to issue corporate zakat. Shareholders should therefore be aware that others are entitled to the wealth they have, so that corporate zakat spending will positively impact their corporate existence and development.

\section{CORPORATE ZAKAT ACCOUNTING CALCULATION METHOD}

Talks on zakat in general and zakat accounting in the academic sphere in particular have undergone significant development. This is not to be overlooked by the many ideas that come from human innovation to achieve a better life. At present, various forms and types of zakat undergo diversification such as stock zakat, corporate zakat, professional zakat, investment zakat and so on. Innovations in the nature of zakat in the span of human life will certainly bring about new types of zakat that are in line with shariah values and not contrary to the requirements of fiqh. Thus, zakat is no longer seen solely as being limited to the scope of religious or shariah studies and discussions, but has grown and embraced economic and social issues. ${ }^{85}$

In relation to accounting and zakat, it has been a widely discussed topic among academics, such as M. H. Al-Moghaiwli (2001), ${ }^{86}$ M. Sulaiman (2003), ${ }^{87}$ Mursyidi (2003), ${ }^{88}$ M.A. Khan (2003), ${ }^{89}$ A.A. Islahi and M. Obaidullah (2004), ${ }^{90}$ Zakaria Bahari and Zahri Hamat (2004), ${ }^{91}$ S.M. Al-Habshi (2005), ${ }^{92}$ A.R. Abdul Rahman (2002, 2007), ${ }^{93}$ and Nur Barizah Abu Bakar (2007), ${ }^{94}$ Hayashi (1989), ${ }^{95}$ Haniffa and Hudaib (2011), ${ }^{96}$ Badsha, et al (2013), ${ }^{97}$ Trokic (2015), ${ }^{98}$ Abdel-Karim (1999), ${ }^{99}$ Said, et al (2012), ${ }^{100}$ Hameed (2009), ${ }^{101}$ Ahmed (2012). ${ }^{102}$ Al-Mazenderany was one of the first Muslim scholars to document accounting practices in the Muslim community. (El-Halaby and Hussainey, 2015), ${ }^{103}$ found that some accounting works from the Islamic point of view can be traced back to their work, such as, Bani-Sadr (1980), ${ }^{104}$ Ezzati (1982), ${ }^{105}$ Fariduddin (1987), ${ }^{106}$ Sharfuddin (1987), ${ }^{107}$ Shirazi (1988), ${ }^{108}$ Chapra (1992), ${ }^{109}$ Rahman and Al-Buraey (1992), ${ }^{110}$ Faridi (1995), ${ }^{111}$ Beekun (1997), ${ }^{112}$ Beekun and Badawi (1999), ${ }^{113}$ Al-Buraey (2003), ${ }^{114}$ Kazmi (2003), ${ }^{115}$ and more recently, Ather (2005), ${ }^{116}$ Abuznaid (2006), ${ }^{117}$ and Beekun (2006), ${ }^{118}$ and Ata alSid (2007), ${ }^{119}$ and Billah and Islam (2011). ${ }^{120}$

The accounting standards broadly refer to the accounting guidelines that 
various institutions have developed and established. This institution sets the standard for implementing accounting and reporting systems related to financial issues. Currently, there are several accounting regulatory bodies. They have issued guidelines for preparing accounting reports. These institutions include The Accounting and Auditing Organization for Islamic Financial Institutions (AAOIFI), The Malaysian Accounting Standard Board (MASB) and the Indonesian Association of Accountants (IAI). ${ }^{121}$ Various types of institutions have now been used as the basis for calculating corporate zakat.

Corporate zakat is a zakat obligation that is required of a company with its status as a legal entity (shakhiyah i'tibariyah) and not as a personal obligation to the owner of the company's assets. Because the benefits of the company are enjoyed together, then its zakat obligations are also borne together. ${ }^{122}$ Every Muslim who carries out trade activities either individually or in the federation, such as carrying on mining, logging, manufacturing, carpentry, wholesale, transportation, housing and grocery business is included in his zakat compulsory business if the conditions of his nisab and haul requirements are met. 354 Qamariah Day. ${ }^{123}$ Thus, the corporate zakat expenditure must be based on the wealth it generates from the profits it generates through its business activities.

Each company has at least three types of assets. First, property in the form of goods, both in the form of facilities and infrastructure as well as in the form of business commodities. Second, the property is in cash, which is usually kept in a bank. Third, property in the form of debt. Business property that is required to be taxed is the three forms of property, minus the property in the form of facilities and infrastructure and other urgent obligations, such as debt due or payable immediately. ${ }^{124}$ However, in corporate zakat expenditure must be seen from the existence of the person who performs the syirkah (cooperation). If all who perform the syirkah are Muslim then the zakat is first issued before the benefits are distributed to the syirkah party, but instead if there are non-Muslim members who perform the syirkah, then the first is released for non-Muslim benefit, then the zakat is only released from the Muslim members, if the amount exceeds lineage. ${ }^{125}$

However, in the Book of al-Amwal it is reported that corporate zakat should be imposed on working capital for a company not just on business items. As Maimun Bin Mahran reports: "When it is time for you to issue a zakat, how much cash do you have, what is the value of the merchandise you have, then evaluate the whole item for cash value, and pay the debt can 
be explained (agreed to pay), and deduct the debt that needs to be paid, and then deduct the remaining zakat". ${ }^{126}$

The above explanation, therefore, may give the impression that the corporate zakat calculation pattern, should be based on financial balance sheet reports by reducing the liability on current assets (current assets). In the sense that all property (other than means and infrastructure) is added to profit, minus the payment of debt and other obligations, and is released $2.5 \%$ as a zakat. While other opinions suggest that corporate zakat is only profitable. So, the difference in the context of determining the zakat property that the company has to issue is based on the results of the jurisprudence of figh scholars and academics. The differences that emerge certainly have their own legal basis in providing a valid argument for making a decision on a zakatbased company property. But fundamentally there is no fundamental difference between the scholars of the figh and the contemporary academics regarding the obligation of the company to issue zakat, so the reconstruction in the corporate zakat arrangement made by contemporary fiqh scholars and Islamic academics has increased the proficiency of Islamic scholars, especially in economic activity. Reconstruction of the classical fiqh does not change the essence of the qath'i, but rather adapts to the current development of socioeconomic conditions. Therefore, the issue of dzanni (ikhtilaf) can be debated and developed as opposed to the sources of the Qur'an and the Hadith.

The enterprise zakat value is equal to the business zakat value of $2.5 \%$. The importance of the zakat value of the company is based on the haul using the qomariah year. However, the use of the biennial year, then the zakat value of the company needs to be adjusted. In the zakat mira of 1984 M/ $1404 \mathrm{H}$ it was agreed that the religious year is longer than the qomariah year around eleven days. Therefore, users of the Shariah year should be able to take into account these differences in setting up a company's time for zakat issuance. As this would have a direct relation to the value of the zakat of the company using the yearly average (365 days) of $2.578 \%$ which is $2.5 \% \times 365 / 354$, so it does not use the $2.5 \%$ value.

There are a few things that are central to making a corporate zakat estimate. First, cash or cash equivalents, secondly, ready-to-trade or business items, thirdly, and fourth, debts. The corporate zakat calculation pattern referred to in the above book of al-Amwaal can be concluded that the balance sheet report is a current asset minus the current liability. This method of calculation is commonly referred to as the Shari'a or Net Assets method. This 
method is used in Saudi Arabia and several other Islamic countries as an approach to performing corporate zakat assessments. In addition to the net asset method, it is also known that the second method is the opposite of the first method, the net capital method. The following steps to take in calculating a corporate zakat can be presented, as follows:

\section{Determining and evaluating Shariah-compliant zakat or property:}

According to Abu Ubaid's previous opinion, hance the scholars have concluded that the zakat imposed on the company is a current asset. The source of data for determining and assessing zakat-related assets is from the financial balance sheet as can be seen in table 1 :

Table 1. Company Assets

\begin{tabular}{ll}
\hline Current asset type & Requirements and Adjustments Required \\
\hline Cash & Subject to zakat \\
\hline Bemp savings & Subjected to zakat after deducting the element of interest \\
investment & Subject to zakat at a market value \\
\hline $\begin{array}{l}\text { Account not yet } \\
\text { received }\end{array}$ & Subject to zakat unless it is truly non-billable \\
\hline Inventory & $\begin{array}{l}\text { All supplies; both those in warehouses, in show rooms, on the streets, and } \\
\text { in distributors in the form of consignment; finished goods; goods in the } \\
\text { production process; or still in the form of raw materials including assets } \\
\text { subject to zakat and all are valued at market prices according to the } \\
\text { meaning of the hadith narrated by Jabir bin Zaid "Judge at the price on the } \\
\text { day the obligation of zakat falls and then remove the zakat. }\end{array}$ \\
\hline $\begin{array}{l}\text { Equipment subject to zakat is equipment which is a component of goods } \\
\text { produced; As for equipment which is not a component of goods produced } \\
\text { does not include property subject to zakat, but is classified as "qoniyyah". } \\
\text { The value used is the market price. }\end{array}$ \\
\hline Shopping pay first
\end{tabular}

Source: Processing results, 2018

The fixed assets of the company do not include the zakat-related property as the Prophet (s) had only ordered the zakat to be released on the property that was ready for sale. The fuqaha means "urudh qoniyyah". 


\section{Determine and evaluate liabilities that reduce the value of the zakat-charged assets (assets).}

Based on Abu Ubaid's earlier opinion, scholars have concluded that deducting liabilities from assets would impose zakat on the company as a current liability. As with any zakat-charged property, the source of data for determining and assessing the deductible liability of the zakat-taxed property is the financial balance as can be seen in table 2 :

Table 2. Corporate Liability

\begin{tabular}{|c|c|}
\hline Current Liability Type & Requirements and Adjustments Required \\
\hline Trade liability & asa subtraction with a value of book value \\
\hline Promise note & asa subtraction with a value of nominal value \\
\hline The liability is still due & asa subtraction with a value of book value \\
\hline Tax liability & as a deduction without the addition of fines or interest \\
\hline Advance paid income & $\begin{array}{l}\text { Its value is calculated on the basis of the value recorded in the contract } \\
\text { without adding or subtracting it. } \\
\text { As for its legal provisions, the following are distinguished: } \\
\text { 1. If the income received is in proportion to the price of the goods that } \\
\text { have not been delivered and the goods are not included in the zakat- } \\
\text { charged property, then it cannot be a deduction. Whereas the goods are } \\
\text { included in the zakat-rich property, they are included as deductions. } \\
\text { 2. If the income received is a payment for services that have not been } \\
\text { provided, then that income includes a reduction in the value of the zakat. }\end{array}$ \\
\hline $\begin{array}{l}\text { Long-term obligations } \\
\text { due }\end{array}$ & asa subtraction with a value of book value \\
\hline Liability Interest & asa subtraction \\
\hline
\end{tabular}

The various methods of assessing the zakat of the company described by Harahap, ${ }^{127}$ as presented by Yusuf al-Qaradhawi, Didin Hafidhuddin, TE Gambling and RA Karim, BAZIS DKI, Takaful Malaysia, Atiyah and AAOIFI have different assessment techniques, based on calculations of These methods are from financial statements especially financial balance sheet and profit and loss reports. Not only does the standard apply to the methods that companies use to calculate zakat-based corporate property, it can certainly cause differences in the methods of zakat calculation for individual companies, and even managing zakat institutions will also make a difference in corporate zakat calculations. Some methods for performing a zakat calculation applied in Indonesia, can be found in the table 3: 
Table 3. Method of Calculating Company Zakat

\begin{tabular}{|c|c|c|}
\hline Standard Formulation & Zakat Rate & Basics of Estimation \\
\hline T.E Gambling \& Karim & $2,5 \%$ & $\{($ Capital + Reserves - Fixed assets $)+$ Net Profit $\} \times 2,5 \%$ \\
\hline Yusuf al-Qardhawi & $2,5 \%$ & (Capital + net profit) $\times 2,5 \%+($ net asset profit x $10 \%)$ \\
\hline Bazis DKI & $2,5 \%$ & (capital + net profit) x $25 \%+($ net asset profit x $10 \%)$ \\
\hline $\begin{array}{l}\text { Syariat Takful } \\
\text { Malaysia Berhand }\end{array}$ & $2,5 \%$ & Profit before zakat and tax $\times 2,5 \%$ \\
\hline $\begin{array}{l}\text { Bank Muamalat } \\
\text { Indonesia }\end{array}$ & $2,5 \%$ & Profit before $\operatorname{tax} \times 2.5 \%$ \\
\hline Didin Hafidhuddin & $2,5 \%$ & $\begin{array}{l}\{(\text { total the net of current assets }+ \text { net profit })-\text { current } \\
\text { liability }\} \times 2,5 \%\end{array}$ \\
\hline $\begin{array}{l}\text { Muhammad Kamal } \\
\text { Atiyah }\end{array}$ & $\begin{array}{l}2.5 \% \text { of } \\
\text { current assets } \\
\text { and } 10 \% \text { of } \\
\text { fixed assets }\end{array}$ & $\begin{array}{l}\text { Harta yang berubah (modal + keuntungan bersih) } x \\
2,5 \% \\
\text { Aset tetap keuntungan aset tetap x } 10 \%\end{array}$ \\
\hline $\begin{array}{l}\text { Qanun N0. } 7 \text { year } \\
2004\end{array}$ & $2,5 \%$ & $\begin{array}{l}\text { Keuntungan yang mencapai nisab dalam masa } 1 \text { tahun } \\
\times 2,5 \%\end{array}$ \\
\hline AAOIFI & $\begin{array}{l}2.5 \% \text { (Hijriah) } \\
\text { or } 2.5775 \% \\
\text { (Masehi) }\end{array}$ & $\begin{array}{l}\text { Net Investment Fund Method = paid-up capital + excess } \\
\text { deductions from assets + profit earned + net income + } \\
\text { unpaid liabilities at the end of the loan repayment year - } \\
\text { (value of fixed assets + unnecessary investments such } \\
\text { as farm to rent + accumulated losses). }\end{array}$ \\
\hline & & $\begin{array}{l}\text { Net Current Asset Method = assets - liabilities +/- } \\
\text { adjustments. }\end{array}$ \\
\hline
\end{tabular}

Source: Harahap ${ }^{128}$

\section{CONCLUSION}

Islam is a religion of guidance given by Allah Almighty to the Prophet Muhammad, teaching through three basic foundations: aqidah, sharia, and morality. This foundation can be implemented in your (Islamic) economic activities using the Qur'an and Hadith sources, as well as the ljtihad. However, the problem is that the development of forms, types, models and methods of activity must, of course, require a reconstruction of the concept of figh through the conception of time and place, as opposed to the values of faith, sharia, morality. Such reconstruction can be done in setting up a company as a subject of zakat, which in the classical study of figh was not found specifically/specifically about corporate zakat. But contemporary fiqh explores the notion of fuqaha in the past by introducing companies like syirkah, whose members join in with more or less people to work together for profit, thus having the obligation to pay zakat. Its essence is the syakhshiyyah i'tibariyyah 
(spritual entity) or the syakhshiyyah hukmiyyah which is referred to as aldhimmah which is a trait attached to human beings, namely, ahliyyah alwujud (right to receive) and ahliyyah al-ada (right to discharge responsibility). Thus, the position of the company can be set as a muzakki in the subject of zakat based on five principles, namely Muslim-owned ownership, must be halal, enterprise assets can be evaluated, enterprise assets can grow and the company's minimum wealth equals 85 grams of gold and other technical requirements. The valuation of zakat issued by the company can be done through the zakat accounting calculation method issued by various Islamic institutions such as The Accounting and Auditing Organization for Islamic Financial Institutions (AAOIFI), The Malaysian Accounting Standard Board (MASB) and the Indonesian Accounting Association (IAI). The problem that arises is that there are differences in the corporate zakat calculations set by each accounting standards institution, so that the results of the zakat obligations paid by the company may vary depending on the corporate zakat accounting standard used. But fundamentally, the company's obligation to pay zakat has been agreed upon by Islamic scholars and scholars in the study of contemporary figh, and the extent to which zakat obligations paid by companies in performing corporate zakat calculations can use one of the legally recognized accounting institutions.

\section{END NOTE}

1 Jabbar, Umar Abdul (n.d) Al Mabadi'ul Fiqhiyyah, Juz 1. Surabaya: Kitab Sumber Ilmu.

2 Thanthawi, Muhammad Sayyid (n.d). al'Aqidah wa al-Akhlak, Mesir: Nahdhatu Mishra

3 Kamali, Muhammad Hasim (2005). Principles of Islamic Jurisprudence. Cambridge, United Kingdom: The Islamic Texts Society.

4 Musa, Muhammad Yusuf (1988). Al-Islam Wa Hajah Al-Insaniyyah Ilayh. Jakarta: Rajawali; Zuhdi, Masjfuk. (1987). Studi Islam. Jakarta: Rajawali; Al-Hanafi (1984). Sharh al-Aqidah at-Tahawizah. Beirut: Al-Maktab al-Islami.

5 Kamali, Op.cit.

6 Al-Farabi, Abu Nashr. (1995). Tahshil al-Sa'adah. Libanon: Dar wa Maktabah al-Hilal; Al-Ghazali, Abu Hamid (1993). Revival of Relegious Learnings Imam Ghazzali's: Ihya Ulum-Id-Din, (trns) Fazl-Ul-Karim. Karachi: Darul-Ishaat

7 Ar-Razi, Fakhruddin (1992). Kitab Al-Nafs Wa'l-Ruh Wa Sharh Quwahuma, (trans) by M. Saghir Hasan Ma'sumi in Imam Razi's Ilm Al-Akhlaq, New Delhi: Kitab Bhavan.

8 Ibnu al-Munzir, Muhammad Ibn Mukarram (1972). Lisan al'Arab. Beirut: Dar al-Fikr; Al-Ghazali (1993), Op.cit. 
9 Ibn Miskawaih (n.d). Tahzib al-Akhlaq wa Tathir al-A'raq. Beirut: Mansyurat Dar Maktabah al-Hayyah.

10 Al-Ghazali (1993), Op.cit.

11 Ibnu Rusyd. (1967). Talkhish Kitab al-Akhlaq li Aristhuthalis (averroes middle commentary on the nicomachean ethics). Seventu Fifth Universary Volume of the Jewish Quarterly Review. Philadelhpia

12 Al-Tusi, Nasir al-Din (1964). Akhlaq-i-Nasiri. The Nasirean Ethics. Ed. G.M. Wickens. London: Allen and Unwin

13 Al-Ghazali (1993), Op.cit.

14 Al-Qoz, Anas Abdul-Hameed (2000). Men Eु The Universe: Reflection of Ibn AlQayyem. Dar-us-Salam Publication.

15 Shahrastani, Muhammad Ibn Abd al-Karim. (1842). Kitâb al-milal wa-al-ni\%al: Book of Religious and Philosophical Sects. London: William Cureton Society for the Publication of Oriental Texts.

16 Ash-shiddiq, Hasbi, (1980). Pengantar Hukum Islam, Yokyakarta: PT Bulan Bintang.

17 Dahlan, Abd. Rahman (2010). Ushul Fiqih. Jakarta: AMZAH.

18 Lane, Edwar William (1986). An Arabic - English Lexicon, Part 4, Beirut-Lebanon: Librairie Du Liban.

19 Ibid.

20 Iqbal, Muhammad (1934). The Reconstruction of Religious Thought in Islam. USA: Oxford University Press.

21 Esposito, J.L. (1999).The Islamic Threat: Myth or Reality?, New York: Oxford University Press.

22 Iqbal, Op.cit.

23 Faruqi, Isma'il Raji (1988). Islamization of Knowledge: Problem, Principles dan Prospective. In Islam:Source and Purpose of Knowledge. USA: International Institute of Islamic Thought.

24 Zaidi, Ali Hasan (2006). Muslim Reconstructions of Knowledge and the Reenchantment of Modernity. Theory Cultural Society. Vol. 23, No. 5.

25 Auda, Jaser (2008). Maqasid Al-Shariah: An Introduction Guide. London: The International Institute of Islamic Thought.

26 Zuhaily, Wahbah (2007). Mu'amalat al-Maliyah al-Mu'asirah. Beirut: Dar alFikr.

27 Suhendi, Hendi (2002). Fiqh Muamalah. Jakarta: Raja Grafindo Persada

28 Haroen, Nasrun H. (2000). Fiqh Muamalah. Jakarta: Gaya Media Pratama.

29 Afandi, M. Yazid (2009). Figh Muamalah dan Implementasinya Dalam Lembaga Keuangan Syari'ah: Dilengkapi Dengan Kamus Istilah Perbankan Syariah. Jakarta: Logung Pustaka.

30 Ayob, Syeikh Hasan (2008). Fiqh Muamalah. Jakarta: Berlian Publication.

31 Ghazaly, Abd Rahman; Ihsan, Ghufron; dan Shidiq, Sapiudin (2010). Fiqh Muamalat. Jakarta: Kecana.

32 Mustofa, Imam (2016). Fiqih Muamalah Kontemporer. Jakarta: RajaGrafindo Persada. 
Moh. Dali, Nuradli Ridzwan Shah (2008). Introduction to Muamalat. Malaysia: Mc Graw-Hill.

34 Ghazi, Abidullah and Ghazi, Tasneema. (2016). An Introduction to Fiqh Mu'amalat. USA: Iqra High School Studies.

35 Abdullah bin Bayyah (2013). Maqasid Al-Mu'amalat Wa Marasid Al-Waqi'at (Purposes of Financial Transactions). Al-Furqan Islamic Heritage Foundation; 3rd Revised

36 Hadzami, Muhammad Syafii (2012). Taudhihul Adillah: Dalil-Dalil Muamalat. Kualam Lumpur: Synergy Media.

37 Qaradawi, Yusuf. (2014). Fiqh al-zakah: dirasah muqaranah li-ahòkamiha wafalsafatiha fi dòaw $1 / 4$ al-Quran wa-al-sunnah. Beirut: Risalah Publishing.

38 Zayas, Farishta G. de (2008). The Law Institution of Zakat. Singapore: Wardah Book.

39 Obaidullah, Mohammed (2015). Revisiting Estimation Methods of Business Zakat and Related Tax Incentives. Emerald Group Publishing Limited.

40 Mardani (2012). Fiqh Ekonomi Syari'ah: Fiqh Muamalah. Jakarta: Kencana; Setiawan, Deny (2013). Kerja Sama (Syirkah) Dalam Ekonomi Islam. Jurnal Ekonomi, Vol. 3, No. 3; Ridho, Muhammad Taufiq. (2007) Zakat Profesi dan Perusahaan, Jakarta: Institut Manajemen Zakat.

41 An-Nabhani, Taqiyyudin. 1996. Membangun Sistim Ekonomi Alternatif Perspektif Islam. Risalah Gusti, Surabaya; Setiawan, Deny (2013). Kerja Sama (Syirkah) Dalam Ekonomi Islam. Jurnal Ekonomi, Vol. 3, No. 3; Mardani (2012). Fiqh Ekonomi Syariah: Fiqh Muamalah. Jakarta: Kencana; Bakhtiar, Bakhtiar (2014) Tinjauan Hukum Islam Terhadap Sistem Bisnis Periklanan AdsenseCamp. Skripsi thesis, Universitas Muhammadiyah Surakarta

42 Ridho, Muhammad Taufiq. (2007) Zakat Profesi dan Perusahaan, Jakarta: Institut Manajemen Zakat.

43 Aristoteles, E. Utrecht. (1962). Pengantar Dalam Hukum Indonesia, Jakarta: Balai Buku Ichtiar; Mas, Marwan (2011). Pengantar Ilmu Hukum. Bogor:Ghalia Indonesia; Soemitro, Rachmat. (1993). Hukum Perseroan Terbatas, Yayasan dan Wakaf. Bandung: PT. Resco.

44 Hafidhuddin, Didin (2007). Agar Harta Berkah dan Bertambah. Jakarta: Gema Insani.

45 Al-Ghazali, Abu Hamid (1997). Al-Wajiz fi Fiqh Mazhabil Imam asy-Syafi'i. Jilid 1. Beirut: Darul Arqom; Ibnu al-Munzir, Op.cit; Al-Zarqa, Mustafa Ahmad (1968), al-Figh al-Islami fi Thawbihi al-Jadid. Dimasyq: Matba'ah Turbayn.

46 Al-Jaziria, Abd al-Rahman. (1990). Al-Fiqh 'ala al-Madhahib al-Arba'ah. Beirut: Dar al-Kutub al-'Ilmiyyah.

47 Sani, Anwar (2010). Jurus Menghimpun Fulus: Manajemen Zakat Berbasis Masjid. Jakarta: PT. Gramedia Pustaka Utama.

48 Zaid, Omar Abdullah, (2004). Accounting Procedures and Recording Prosedures in The Early Islamic State. Accounting Historical Journal, Vol. 31, No. 2

49 Ibid.

50 Al-Badrawi, Abd al-Mun'im. (n.d) al-Madkhal li al-Ulum al-Qanuniyyah, Bairut: 
Dar al-Kitab al-Arabi

51 Lewis, M.K. (2001). Islam and Accounting, Accounting Forum, 25(2), 103-127.

52 Abdul Rahim, A. R. (2003). Zakat on Business Wealth in Malaysia: Corporate Tax Rebate, Accountability, and Governance. Jurnal IKIM. Volume 11, No. 1.

53 Lewis, Op.cit

54 Haniffa, R. \& Hudaib, M. (2011) A Conceptual Framework for Islamic Accounting, in Napier, C. \& Haniffa, R. (eds.), Islamic Accounting, Edward Elgar.

55 Amin Rahmanurrasjid. (2008). Akuntabilitas dan Transparansi dalam Pertanggungjawaban Pemerintah Daerah Untuk Mewujudkan Pemerintahan yang Baik di Daerah. Tesis - Universitas Diponegoro Semarang.

56 Badshah, Imtiaz; Mellemvik,Frode; and Timoshenko, Konstantin (2013). Accounting From A Religious Perspective: A Case of The Central Government Accounting In Islamic Republic of Pakistan. Asian Economic and Financial Review, 2013, 3(2):243-258.

57 Adnan, Muhammad Akhyar and Barizah, Nur. (2009) Accounting Treatment for Corporate Zakat: A Critical Review." International Journal of Islamic and Middle Eastern Finance and Management. Vol. 2, No. 1, pp. 32-45.

58 Kahf, Monzer. (1999). The principle of socio-economic justice in the contemporary fiqh of Zakah. The Iqtisad, University Islam Indonesia: CIESD; Mas'udi, Masdar F. (1993). Agama Keadilan Risalah Zakat (Pajak) Dalam Islam, Jakarta: Pustaka Firdaus; Abdul Rahman, Abdul Rahim. (2002). An Islamic Perspective on Corporate Accountability and Morality. Gajah Mada International Journal of Business, Vol. 4 No. 1; Hidayat Fatah dan Nurrani. Zakat Hasil Pertanian Kontemporer. Jurnal Fiqh. Vol. 13, No. 2, 2013.

59 Nur Barizah, A., (2007). A Zakat Accounting Standard (ZAS) for Malaysian companies. American Journal of Islamic Social Sciences, 4(24), pp. 74-92.

60 Ad Damsyiqi, Ibnu Hamzah Al Husaini Al Hanafi. (1997). Asbabul Wurud I Latar Belakang Historis Timbulnya Hadits-Hadits Rasul. (terj) Suwarta Wijaya dan Zafrullah Salim. Jakarta: Kalam Mulia.

61 Al-Zuhayli, Wahbah. 1997. Al-Fiqh al-Islam wa Adillatuh. Vol. 3. Damaskus: Dar al-Fikr.

62 Qaradawi, Op.cit.

63 Ibid.

64 Ibid.

65 Ash-shiddiq, Hasbi, (1980). Pengantar Hukum Islam, Yokyakarta: PT Bulan Bintang.

66 Ibid.

67 Hafidhuddin, Didin (2002). Zakat dalam Perekonomian Modern. Jakarta: Gema Insani. Press

68 Al Tariqi, Abdullah Abdul Husain (2004), Ekonomi Islam Prinsip Dasar dan Tujuan, (terj) M. Irfan Syofwani Yogyakarta: Magistra Insania Press; Djakfar, Muhammad, (2012) Etika Bisnis Menangkap Spirit Ajaran Langit dan Pesan Moral Ajaran Bumi, Jakarta: Penebar Plus; Hasanah, Uswatun, "Perkembangan Wakaf di Dunia Islam” dalam Suhrawardi K. Lubis, (2010) Wakaf dan Pemberdayaan 
Umat, Jakarta: Sinar Grafika.

Lubis, Suhrawardi K. (2000), Hukum Ekonomi Islam, Jakarta: Sinar Grafika; Djakfar, Muhammad. (2007) Agama, Etika, dan Ekonomi; Wacana Menuju Pengembangan Ekonomi Rabbaiyah, Malang: UIN Malang Press..

Djakfar, Muhammad, (2012) Etika Bisnis Menangkap Spirit Ajaran Langit dan Pesan Moral Ajaran Bumi, Jakarta: Penebar Plus; Hafidhuddin (2007), Op.cit.

71 Meera, A. K.M. \& Larbani M. (2009), Ownership Effects of Fractional Reserve System Homanomics, Vol. 25, No. 4, pp. 101-116.

72 Rahman, T. (2015). Akuntansi Zakat, Infak dan Sedekah (PSAK 109): Upaya Peningkatan Transparansi dan Akuntabilitas Organisasi Pengelola Zakat (OPZ). Jurnal Muqtasid, 6(109), 141-164

73 Purwanto. (2009). Manajemen Fundraising bagi Organisasi Pengelola Zakat, Yogyakarta: Pustaka.

74 Qaradawi, Op.cit.

75 Wiyono, Slamet, 2005, Cara mudah Memahami Akutansi Perbankan Syari'ah, Jakarta; PT Grasindo.

76 Al-Ghazali (1997), Op.cit

77 Sulaiman, Muhammad \& Zakaria A. (2010). Jejak Bisnis Rasul. Jakarta: Mizan.

78 Hafidhuddin (2002), Op.cit.

79 Zuhaily, Opt.cit.

80 Syed Sabiq (2006). Fiqih Sunnah, Juz 4. Jakarta: Pena Pundi Aksara

81 Rumah Amal (2015). Zakat Perusahaan. http://webcache.googleusercontent.com/search?q=cache:ZuZoQJkZtPoJ:blog.rumahamal.org/category/ziswaf/ edukasi-ziswaf/page/3/+\&cd=9\&hl=id\&ct=clnk\&gl=id, Acces, May 20, 2015

82 Farhan, Ali dan Triyuwono, Iwan. (2013) Metode Perhitungan Zakat Perusahaan Pada CV. Minakjinggo. Jurnal Ilmiah Mahasiswa FEB. Malang: Universitas Brawijaya.

83 Qaradawi, Op.cit; Shahatah, Husain (2003). Kaedah Agihan Zakat Harta, Pengertian, Sistem dan Agihannya, (terj). Hamid Fahmy Zarkasyi dan Harun Ar-Rashid Hj. Tuskan, Kuala Lumpur: Pustaka Al-Shafa; Abd Majid, Mahmood Zuhdi (2003). Pengurusan Zakat, Kuala Lumpur: Dewan Bahasa dan Pustaka; Syed Mohd Ghazali Wafa, S.A.W. (2004). Corporate Zakat Accounting-Understanding of Zakat Business Zakat Assessment Methods ("Zakat corporate accountingUnderstanding of Zakat Assessment Methods"). Paper Presented at the Corporate Zakat Halatuju in New Millennium, Universiti Kebangsaan Malaysia Selangor, Malaysia.

84 Abd Majid, Mahmood Zuhdi (2003). Pengurusan Zakat, Kuala Lumpur: Dewan Bahasa dan Pustaka

85 Adnan\& Barizah, Op.cit.

86 Al-Moghaiwli, M.H. (2001), "Accounting for zakat and earnings management in Saudi Arabia”, Journal of Accounting, Accountability and Performance, Vol. 7 No. 1.

87 Sulaiman, Maliah bt. 2003. The Influence of Riha and 'Zakat on Islamic Accounting. Indonesian Management and Accounting Review (2003), Vol 2 (2), 149. 
167. Kuala Lumpur: International Islamic University Malaysia.

Mursyidi, 2003, Akuntansi Zakat Kontemporer, PT.Remaja Rosdakarya Offset, Bandung

89 Khan, M. A. (2003). Zakah accounting and auditing: Principles, rules and experience in Pakistan. Islamic Economic Studies, Vol. 10, No. 2.

90 Islahi, A.A. and Obaidullah, M. (2004), "Zakah on stocks: some unsettled issues", Journal of King

91 Bahari, Z. and Hamat, Z. (2004), "Rethinking zakat on employment income: the case of Malaysia”, paper presented at 6th ASEAN Inter-University Seminars on Social Development, Penang, May 14-16

92 Al-Habshi, S.M. (2005), "Zakat recognition and measurement of business wealth: an analysis of the growth condition", in Shanmugam, B. et al. (Eds), Issues in Islamic Accounting, University Putra Malaysia Press, Serdang.

93 Abdul Rahman, A.R. (2002), "Zakat accounting, creating business wealth", Akauntan Nasional, August, pp. 11-16 ; Abdul Rahman, A.R. (2007), Prerequisites for effective integration of zakah into mainstream Islamic financial system in Malaysia, Islamic Economic Studies, Vol. 4 No. 2, pp. 91-107.

94 Nur Barizah, Op.cit

95 Hayashi, Tosika. (1989). On Islamic Accounting: Its Future Impact on Western Accounting, Niigataken, Japan: IMES, University of Japan

96 Haniffa \& Hudaib, Op.cit.

97 Badshah, Imtiaz; Mellemvik,Frode; and Timoshenko, Konstantin (2013). Accounting From A Religious Perspective: A Case of The Central Government Accounting In Islamic Republic of Pakistan. Asian Economic and Financial Review, 2013, 3(2):243-258.

98 Trokic, A. (2015). Islamic Accounting: History, Development and Prospects. European Journal of Islamic Finance, Vol. 3, No. 12, pp. 1-6.

99 Abdel-Karim. RifaatAhmed, (199). 'Accounting and Auditing Standards for Islamic FinancialInstitutions', Proceedings of the Second Harvard University Forum on Islamic Finance: Islamic Financeinto the 21 Century, (Cambridge, Massachusetts: Center for Middle Eastern Studies, Harvard University.

100 Said, J., Ghani, E.K., Zawawi, S.N.H \& Syed Yusof, S.N. (2012).Composite Performance Measurement for Zakat Organisations. British Journal of Economics, Finance and Management Sciences, 4(1), 50-59

101 Hameed, S. (2009). Accounting and Auditing for Islamic Financial Institutions. Kuala Lumpur (Edition): International Centre for Education in Islamic Finance (INCEIF).

102 Ahmed, A.A.A. (2012). Accounting in Islamic Perspective: A Timely Opportunity Challenge. ASA University Review, 6(2), 11-30.

103 El-Halaby, S., \& Hussainey, K. (2015). The Determinants of Social Accountability Disclosure: Evidence From Islamic Banks Around The World. International Journal of Business, 20(3), 202-223

104 Bani-Sadr, A. (1980). Work and the worker in Islam. Tehran, Hamdani Foundations 
Ezzati, A. (1982) The concept of leadership in Islam. Al- Nahdah 2 (2): 24-29

106 Fariduddin, M.(1987). Workers right in Islam. Bangladesh: Islamic Foundation.

107 Sharfuddin, I. O.M. (1987), Towards an Islamic Administrative Theory. The American Journal of Islamic social Sciences 4(2):229-244.

108 Shirazi, AN.M. (1988). Management and Leadership in the Life of the Prophet(S)," al- Tawhid, 5 (2): 157-165

109 Chapra, M.U. (1992). Islam and the Economic Challenge. International Institute of Islamic Thought, Herndon, VA. USA

110 Rahman, M. and al- Buraey, M. (1992). An Islamic perspective of organizational controls and performance evaluation. The American Journal of Islamic Social Sciences 9 (4)

111 Faridi, F.r. (1995, Ed.). Islamic Principles of Business Organization and Management. New Delhi: Qazi Publishers and Distributors

112 Beekun, R.I. (1997). Islamic Business Ethics, USA: The International Institute of Islamic Thought.

113 Beekun, R.I. and Badawi, J. (1999). Leadership: An Islamic Perspective, Herndon, VA: Amana Publications.

114 Al-Buraey, Muhammad A. (2003). Management and Administration in Islam. Bangalore, India: Iqua Welfare Publications

115 Kazmi, A (2003). A proposed research agenda from Islamic perspectives to management studies. IIUM Journal of Economics and Management 11 (2): 197-228.

116 Ather, S.M. (2005). Islamic Management and Business, International Islamic University, Chittagong, Bangladesh.

117 Abuznaid, S. (2006). Islam and Management: What Can Be Learned? Thunderbird International Business Review, 48: 125-139.

118 Beekun, R. I. (2006). Strategic Planning and Implementation for Islamic Organizations. Virginia: The International Institute of Islamic Thought

119 Ata al-Sid, M. (2007). Contemporary Attempts at Overcoming Decadence and Revitalizing Qur'anic Thought. Business Review 2(1): 56-75.

120 Billah, Alim Al Ayub Ahmed Arif and Islam, Md Alidul (2011). Accounting in Islamic Perspective: A Timely Opportunity, a Timely Challenge. IIUC STUDIES, Vol.- 9, pp. 187-214

121 Adnan \& Barizah, Op.cit.

122 Hafidhuddin, Didin. (1998). Panduan Praktis Tentang Zakat, Infak, Sedekah. Jakarta: Gema Insani; Zaid, O.A. (2004). Accounting Systems and Recording Procedures in the Early Islamic State. The Accounting Historians Journal. 31(2), 149-170; Sani, M Anwar. (2010). Jurus Menghimpun Fulus Manajemen Zakat Berbasis Masjid, Jakarta: PT Gramedia Pustaka Utama.

123 Hassan, Mat Saad. (1986). "Zakat dan Cukai Pendapatan di Malaysia”, (Kertas Kerja, Seminar Zakat dan Cukai di Malaysia, pada 5 Mei 1986, anjuran Persatuan Kebajikan Islam Hasil Dalam Negeri Kuala Lumpur, Baitulmal Wilayah Persekutuan dan Persatuan Ulamak Malaysia). 
124 Hafidhuddin, Didin (2008) The power of zakat: Studi perbandingan pengelolaan zakat di Asia Tenggara. UIN-Maliki Press, Malang

125 Purwanto, Op.cit.

126 AbuUbayd al-Qasim b. Salam. (1991). Kitab al-Amwal, (terj). Noor Mohammad Ghiffari Islamabad: Pakistan Hijra Council.

127 Harahap, Sofyan Syafri (2001). Prinsip-Prinsip Akuntansi Islam. Media Riset Akuntansi, Auditing \& Information. Vol. 1, No. 1

128 Harahap, Op.cit.

\section{REFERENCES}

Abd Majid, Mahmood Zuhdi (2003). Pengurusan Zakat, Kuala Lumpur: Dewan Bahasa dan Pustaka.

Abdalati, Hammudah (1986). Islam Suatu Kepastian. Saudi Arabia: International Islamic Federation of Student Organization.

Abdel-Karim. RifaatAhmed, (199). 'Accounting and Auditing Standards for Islamic FinancialInstitutions', Proceedings of the Second Harvard University Forum on Islamic Finance: Islamic Financeinto the 21 Century, (Cambridge, Massachusetts: Center for Middle Eastern Studies, Harvard University.

Abdul Rahim, A.R. (2003). Zakat on Business Wealth in Malaysia: Corporate Tax Rebate, Accountability, and Governance. Jurnal IKIM. Volume 11, No. 1.

Abdul Rahman, A.R. (2002). An Islamic Perspective on Corporate Accountability and Morality. Gajah Mada International Journal of Business, Vol. 4 No. 1.

Abdul Rahman, A.R. (2002). Zakat accounting, creating business wealth, Akauntan Nasional, August, pp. 11-16.

Abdul Rahman, A.R. (2007), Pre-requisites for effective integration of zakah into mainstream Islamic financial system in Malaysia, Islamic Economic Studies, Vol. 4 No. 2, pp. 91-107.

Abdullah bin Bayyah (2013). Maqasid Al-Mu'amalat Wa Marasid Al-Waqi'at (Purposes of Financial Transactions). Al-Furqan Islamic Heritage Foundation; 3rd Revised

AbuUbayd al-Qasim b. Salam. (1991). Kitab al-Amwal, (terj). Noor Mohammad Ghiffari Islamabad: Pakistan Hijra Council.

Abuznaid, S. (2006). Islam and Management: What Can Be Learned? Thunderbird International Business Review, 48: 125-139.

Ad Damsyiqi, Ibnu Hamzah Al Husaini Al Hanafi. (1997). Asbabul Wurud I Latar Belakang Historis Timbulnya Hadits-Hadits Rasul. (terj) Suwarta Wijaya dan Zafrullah Salim. Jakarta: Kalam Mulia.

Adnan, Muhammad Akhyar and Barizah, Nur. (2009) Accounting Treatment for Corporate Zakat: A Critical Review." International Journal of Islamic and Middle Eastern Finance and Management. Vol. 2, No. 1, pp. 32-45.

Afandi, M. Yazid (2009). Fiqh Muamalah dan Implementasinya Dalam Lembaga Keuangan Syari'ah: Dilengkapi Dengan Kamus Istilah Perbankan Syariah. Jakarta: Logung Pustaka.

Ahmed, A.A.A. (2012). Accounting in Islamic Perspective: A Timely Opportunity 
Challenge. ASA University Review, 6(2), 11-30.

Al Tariqi, Abdullah Abdul Husain (2004), Ekonomi Islam Prinsip Dasar dan Tujuan, (terj) M. Irfan Syofwani Yogyakarta: Magistra Insania Press.

Al-Badrawi, Abd al-Mun'im. (n.d) al-Madkhal li al-Ulum al-Qanuniyyah, Bairut: Dar al-Kitab al-'Arabi

Al-Buraey, Muhammad A. (2003). Management and Administration in Islam. Bangalore, India: Iqua Welfare Publications

Al-Farabi, Abu Nashr. (1995). Tahshil al-Sa'adah. Libanon: Dar wa Maktabah alHilal.

Al-Ghazali, Abu Hamid (1993). Revival of Relegious Learnings Imam Ghazzali's: Ihya Ulum-Id-Din, (trns) Fazl-Ul-Karim. Karachi: Darul-Ishaat.

Al-Ghazali, Abu Hamid (1997). Al-Wajiz fi Fiqh Mazhabil Imam asy-Syafi'i. Jilid 1. Beirut: Darul Arqom.

Al-Habshi, S.M. (2005), "Zakat recognition and measurement of business wealth: an analysis of the growth condition”, in Shanmugam, B. et al. (Eds), Issues in Islamic Accounting, University Putra Malaysia Press, Serdang.

Al-Jaziria, Abd al-Rahman. (1990). Al-Figh 'ala al-Madhahib al-Arba'ah. Beirut: Dar al-Kutub al-'Ilmiyyah.

Al-Moghaiwli, M.H. (2001), "Accounting for zakat and earnings management in Saudi Arabia”, Journal of Accounting, Accountability and Performance, Vol. 7 No. 1.

Al-Qoz, Anas Abdul-Hameed (2000). Men $\mathcal{G}$ The Universe: Reflection of Ibn AlQayyem. Dar-us-Salam Publication.

Al-Shayirazi, Abu Ishak Ibrahim Ali (2013). Al-Luma' fi Usul al-Figh. Bahrain: Dar al-Hadith al-Kittaniyyah.

Al-Tusi, Nasir al-Din (1964). Akhlaq-i-Nasiri. The Nasirean Ethics. Ed. G.M. Wickens. London: Allen and Unwin

Al-Zarqa, Mustafa Ahmad (1968), al-Fiqh al-Islami fi Thawbihi al-Jadid. Dimasyq: Matba'ah Turbayn.

Al-Zuhayli, Wahbah. 1997. Al-Fiqh al-Islam wa Adillatuh. Vol. 3. Damaskus: Dar alFikr.

Amin Rahmanurrasjid. 2008. Akuntabilitas dan Transparansi dalam Pertanggungjawaban Pemerintah Daerah Untuk Mewujudkan Pemerintahan yang Baik di Daerah. Tesis - Universitas Diponegoro Semarang.

An-Nabhani, Taqiyyudin. 1996. Membangun Sistim Ekonomi Alternatif Perspektif Islam. Risalah Gusti, Surabaya.

Aristoteles, E. Utrecht. (1962). Pengantar Dalam Hukum Indonesia, Jakarta: Balai Buku Ichtiar.

Ar-Razi, Fakhruddin (1992). Kitab Al-Nafs Wa'l-Ruh Wa Sharh Quwahuma, (trans) by M. Saghir Hasan Ma'sumi in Imam Razi's Ilm Al-Akhlaq, New Delhi: Kitab Bhavan.

Ash-shiddiq, Hasbi, (1980). Pengantar Hukum Islam, Yokyakarta: PT Bulan Bintang. Ata al-Sid, M. (2007). Contemporary Attempts at Overcoming Decadence and Revitalizing Qur'anic Thought. Business Review 2(1): 56-75. 
Ather, S.M. (2005). Islamic Management and Business, International Islamic University, Chittagong, Bangladesh.

Auda, Jaser (2008). Maqasid Al-Shariah: An Introduction Guide. London: The International Institute of Islamic Thought.

Ayob, Syeikh Hasan (2008). Fiqh Muamalah. Jakarta: Berlian Publication.

Badshah, Imtiaz; Mellemvik,Frode; and Timoshenko, Konstantin (2013). Accounting From A Religious Perspective: A Case of The Central Government Accounting In Islamic Republic of Pakistan. Asian Economic and Financial Review, 2013, $3(2): 243-258$.

Bahari, Z. and Hamat, Z. (2004), "Rethinking zakat on employment income: the case of Malaysia”, paper presented at 6th ASEAN Inter-University Seminars on Social Development, Penang, May 14-16

Bakhtiar, Bakhtiar (2014) Tinjauan Hukum Islam Terhadap Sistem Bisnis Periklanan AdsenseCamp. Skripsi thesis, Universitas Muhammadiyah Surakarta

Bani-Sadr, A. (1980). Work and the worker in Islam. Tehran, Hamdani Foundations

Basyir, Ahmad Azhar. (1992). Refleksi Atas Persoalan Keislaman. Bandung: Mizan; Umer, M. Chapra (1992). Islam and The Economic Challenges. USA: The Islamic Foundation and The International Institute of Islamic Thought.

Beekun, R.I. (1997). Islamic Business Ethics, USA: The International Institute of Islamic Thought.

Beekun, R.I. (2006). Strategic Planning and Implementation for Islamic Organizations. Virginia: The International Institute of Islamic Thought

Beekun, R.I. and Badawi, J. (1999). Leadership: An Islamic Perspective, Herndon, VA: Amana Publications.

Billah, Alim Al Ayub Ahmed Arif and Islam, Md Alidul (2011). Accounting in Islamic Perspective: A Timely Opportunity, a Timely Challenge. IIUC STUDIES, Vol.- 9, pp. 187-214

Chapra, M.U. (1992). Islam and the Economic Challenge. International Institute of Islamic Thought, Herndon, VA. USA

Dahlan, Abd. Rahman (2010). Ushul Fiqih. Jakarta: AMZAH.

Djakfar, Muhammad, (2012) Etika Bisnis Menangkap Spirit Ajaran Langit dan Pesan Moral Ajaran Bumi, Jakarta: Penebar Plus.

Djakfar, Muhammad. (2007) Agama, Etika, dan Ekonomi; Wacana Menuju Pengembangan Ekonomi Rabbaiyah, Malang: UIN Malang Press..

El-Halaby, S., \& Hussainey, K. (2015). The Determinants of Social Accountability Disclosure: Evidence From Islamic Banks Around The World. International Journal of Business, 20(3), 202-223

Esposito, J.L. (1999).The Islamic Threat: Myth or Reality?, New York: Oxford University Press.

Ezzati, A. (1982) The concept of leadership in Islam. Al- Nahdah 2 (2): 24-29

Farhan, Ali dan Triyuwono, Iwan. (2013) Metode Perhitungan Zakat Perusahaan Pada CV. Minakjinggo. Jurnal Ilmiah Mahasiswa FEB. Malang: Universitas Brawijaya. 
Faridi, F.r. (1995, Ed.). Islamic Principles of Business Organization and Management. New Delhi: Qazi Publishers and Distributors

Fariduddin, M.(1987). Workers right in Islam. Bangladesh: Islamic Foundation.

Faruqi, Isma'il Raji (1988). Islamization of Knowledge: Problem, Principles dan Prospective. In Islam:Source and Purpose of Knowledge. USA: International Institute of Islamic Thought.

Ghazaly, Abd Rahman; Ihsan, Ghufron; dan Shidiq, Sapiudin (2010). Fiqh Muamalat. Jakarta: Kecana.

Ghazi, Abidullah and Ghazi, Tasneema. (2016). An Introduction to Fiqh Mu'amalat. USA: Iqra High School Studies.

Hadzami, Muhammad Syafii (2012). Taudhihul Adillah: Dalil-Dalil Muamalat. Kualam Lumpur: Synergy Media.

Hafidhuddin, Didin (2002). Zakat dalam Perekonomian Modern. Jakarta: Gema Insani. Press

Hafidhuddin, Didin (2007). Agar Harta Berkah dan Bertambah. Jakarta: Gema Insani.

Hafidhuddin, Didin (2008) The power of zakat: Studi perbandingan pengelolaan zakat di Asia Tenggara. UIN-Maliki Press, Malang

Hameed, S. (2009). Accounting and Auditing for Islamic Financial Institutions. Kuala Lumpur (Edition): International Centre for Education in Islamic Finance (INCEIF).

Haniffa, R. \& Hudaib, M. (2011) A Conceptual Framework for Islamic Accounting, in Napier, C. \& Haniffa, R. (eds.), Islamic Accounting, Edward Elgar.

Harahap, Sofyan Syafri (2001). Prinsip-Prinsip Akuntansi Islam. Media Riset Akuntansi, Auditing $\mathcal{E}$ Information. Vol. 1, No. 1

Haroen, Nasrun H. (2000). Fiqh Muamalah. Jakarta: Gaya Media Pratama.

Hasanah, Uswatun, "Perkembangan Wakaf di Dunia Islam” dalam Suhrawardi K. Lubis, (2010) Wakaf dan Pemberdayaan Umat, Jakarta: Sinar Grafika.

Hassan, Mat Saad. 1986. "Zakat dan Cukai Pendapatan di Malaysia”, (Kertas Kerja, Seminar Zakat dan Cukai di Malaysia, pada 5 Mei 1986, anjuran Persatuan Kebajikan Islam Hasil Dalam Negeri Kuala Lumpur, Baitulmal Wilayah Persekutuan dan Persatuan Ulamak Malaysia).

Hayashi, Tosika. (1989). On Islamic Accounting: Its Future Impact on Western Accounting, Niigataken, Japan: IMES, University of Japan

Hidayat Fatah dan Nurrani. Zakat Hasil Pertanian Kontemporer. Jurnal Fiqh. Vol. 13, No. 2, 2013.

Ibn Khaldun, Abu Zayd Abdurrahman (n.d). Muqaddimah. Beirut: Dar al-Jail.

Ibn Miskawaih (n.d). Tahzib al-Akhlaq wa Tathir al-A'raq. Beirut: Mansyurat Dar Maktabah al-Hayyah.

Ibnu al-Munzir, Muhammad Ibn Mukarram (1972). Lisan al-'Arab. Beirut: Dar alFikr.

Ibnu Qudamah, Abd Allah Ibn Ahmad (1986). Al Mughni. (ed) Abd Allah al Turki et al. Cairo: Dar hajar

Ibnu Rusyd. (1967). Talkhish Kitab al-Akhlaq li Aristhuthalis (averroes middle 
commentary on the nicomachean ethics). Seventu Fifth Universary Volume of the Jewish Quarterly Review. Philadelhpia

Iqbal, Muhammad (1934). The Reconstruction of Religious Thought in Islam. USA: Oxford University Press.

Islahi, A.A. and Obaidullah, M. (2004), "Zakah on stocks: some unsettled issues”, Journal of King

Jabbar, Umar Abdul (n.d) Al Mabadi'ul Fiqhiyyah, Juz 1. Surabaya: Kitab Sumber Ilmu.

Jauhar, Ahmad Al-Mursi Husain (2010). Maqashid Syariah, Jakarta:Amzah

Kahf, Monzer. (1999). The principle of socio-economic justice in the contemporary fiqh of Zakah. The Iqtisad, University Islam Indonesia: CIESD.

Kamali, Muhammad Hasim (2005). Principles of Islamic Jurisprudence. Cambridge, United Kingdom: The Islamic Texts Society.

Kazmi, A (2003). A proposed research agenda from Islamic perspectives to management studies. IIUM Journal of Economics and Management 11 (2): 197-228.

Khan, M. A. (2003). Zakah accounting and auditing: Principles, rules and experience in Pakistan. Islamic Economic Studies, Vol. 10, No. 2.

Lane, Edwar William (1986). An Arabic - English Lexicon, Part 4, Beirut-Lebanon: Librairie Du Liban.

Lewis, M.K. (2001). Islam and Accounting, Accounting Forum, 25(2), 103-127.

Lubis, Suhrawardi K. (2000), Hukum Ekonomi Islam, Jakarta: Sinar Grafika.

Mardani (2012). Fiqh Ekonomi Syari'ah: Fiqh Muamalah. Jakarta: Kencana.

Mas, Marwan (2011). Pengantar Ilmu Hukum. Bogor:Ghalia Indonesia; Soemitro, Rachmat. (1993). Hukum Perseroan Terbatas, Yayasan dan Wakaf. Bandung: PT. Resco.

Mas'udi, Masdar F. (1993). Agama Keadilan Risalah Zakat (Pajak) Dalam Islam, Jakarta: Pustaka Firdaus.

Meera, A. K.M. \& Larbani M. (2009), Ownership Effects of Fractional Reserve System Homanomics, Vol. 25, No. 4, pp. 101-116.

Moh. Dali, Nuradli Ridzwan Shah (2008). Introduction to Muamalat. Malaysia: Mc Graw-Hill.

Mursyidi, 2003, Akuntansi Zakat Kontemporer, PT.Remaja Rosdakarya Offset, Bandung

Musa, Muhammad Yusuf (1988). Al-Islam Wa Hajah Al-Insaniyyah Ilayh. Jakarta: Rajawali.

Mustofa, Imam (2016). Fiqih Muamalah Kontemporer. Jakarta: RajaGrafindo Persada.

Nur Barizah, Abu Bakar. (2007). A Zakat Accounting Standard (ZAS) for Malaysian companies. American Journal of Islamic Social Sciences, 4(24), pp. 74-92.

Nur Barizah, Abu Bakar. (2007). Study Guide: Zakat Accounting Concepts and Application. Kuala Lumpur: Wise Words Publishing

Obaidullah, Mohammed (2015). Revisiting Estimation Methods of Business Zakat and Related Tax Incentives. Emerald Group Publishing Limited.

Purwanto. (2009). Manajemen Fundraising bagi Organisasi Pengelola Zakat, Yogyakarta: Pustaka. 
Qaradawi, Yusuf. (2014). Fiqh al-zakah: dirasah muqaranah li-ahòkamiha wa-falsafatiha fi dòaw1/4 al-Quran wa-al-sunnah. Beirut: Risalah Publishing.

Rahman, M. and al- Buraey, M. (1992). An Islamic perspective of organizational controls and performance evaluation. The American Journal of Islamic Social Sciences 9 (4)

Rahman, T. (2015). Akuntansi Zakat, Infak dan Sedekah (PSAK 109): Upaya Peningkatan Transparansi dan Akuntabilitas Organisasi Pengelola Zakat (OPZ). Jurnal Muqtasid, 6(109), 141-164

Ridho, Muhammad Taufiq. (2007) Zakat Profesi dan Perusahaan, Jakarta: Institut Manajemen Zakat.

Rumah Amal (2015). Zakat Perusahaan. http://webcache.googleusercontent.com/ search?q=cache:ZuZoQJkZtPoJ:blog.rumahamal.org/category/ziswaf/edukasiziswaf/page $/ 3 /+\& c d=9 \&$ hl=id\&ct=clnk\&gl=id, Acces, May 20, 2015

Said, J., Ghani, E.K., Zawawi, S.N.H \& Syed Yusof, S.N. (2012).Composite Performance Measurement for Zakat Organisations. British Journal of Economics, Finance and Management Sciences, 4(1), 50-59

Sani, Anwar (2010). Jurus Menghimpun Fulus: Manajemen Zakat Berbasis Masjid. Jakarta: PT. Gramedia Pustaka Utama.

Setiawan, Deny (2013). Kerja Sama (Syirkah) Dalam Ekonomi Islam. Jurnal Ekonomi, Vol. 3, No. 3.

Shahatah, Husain (2003). Kaedah Agihan Zakat Harta, Pengertian, Sistem dan Agihannya, (terj). Hamid Fahmy Zarkasyi dan Harun Ar-Rashid Hj. Tuskan, Kuala Lumpur: Pustaka Al-Shafa.

Shahrastani, Muhammad Ibn Abd al-Karim. (1842). Kitâb al-milal wa-al-ni\%al: Book of Religious and Philosophical Sects. London: William Cureton Society for the Publication of Oriental Texts.

Sharfuddin, I. O.M. (1987), Towards an Islamic Administrative Theory. The American Journal of Islamic social Sciences 4(2):229-244.

Shirazi, AN.M. (1988). Management and Leadership in the Life of the Prophet(S), al- Tawhid, 5 (2): 157-165

Suhendi, Hendi (2002). Fiqh Muamalah. Jakarta: Raja Grafindo Persada

Sulaiman, Maliah bt. 2003. The Influence of Riha and 'Zakat on Islamic Accounting. Indonesian Management and Accounting Review (2003), Vol 2 (2), 149-167. Kuala Lumpur: International Islamic University Malaysia.

Sulaiman, Muhammad \& Zakaria A. (2010). Jejak Bisnis Rasul. Jakarta: Mizan. Syaltut, Muhammad (1966). Al-Islam Aqidah wa Syari'ah. Cairo: Dar al-Kalam Syed Mohd Ghazali Wafa, S.A.W. (2004). Corporate Zakat Accounting-Understanding of Zakat Business Zakat Assessment Methods ("Zakat corporate accounting-Understanding of Zakat Assessment Methods"). Paper Presented at the Corporate Zakat Halatuju in New Millennium, Universiti Kebangsaan Malaysia Selangor, Malaysia.

Syed Sabiq (2006). Fiqih Sunnah, Juz 4. Jakarta: Pena Pundi Aksara

Thanthawi, Muhammad Sayyid (n.d). al'Aqidah wa al-Akhlak, Mesir: Nahdhatu Mishra. 
Trokic, A. (2015). Islamic Accounting: History, Development and Prospects. European Journal of Islamic Finance, Vol. 3, No. 12, pp. 1-6.

Wiyono, Slamet, 2005, Cara mudah Memahami Akutansi Perbankan Syari'ah, Jakarta; PT Grasindo.

Zaid, Omar Abdullah, (2004). Accounting Procedures and Recording Prosedures in The Early Islamic State. Accounting Historical Journal, Vol. 31, No. 2

Zaidi, Ali Hasan (2006). Muslim Reconstructions of Knowledge and the Re-enchantment of Modernity. Theory Cultural Society. Vol. 23, No. 5.

Zayas, Farishta G. de (2008). The Law Institution of Zakat. Singapore: Wardah Book.

Zuhaily, Wahbah (2007). Mu'amalat al-Maliyah al-Mu'asirah. Beirut: Dar al-Fikr.

Zuhdi, Masjfuk. (1987). Studi Islam. Jakarta: Rajawali; Al-Hanafi (1984). Sharh alAqidah at-Tahawiyah. Beirut: Al-Maktab al-Islami. 